Lukasz Gaweł (D) https://orcid.org/0000-0002-0504-3750

Uniwersytet Jagielloński, Wydział Zarządzania i Komunikacji Społecznej, Instytut Kultury e-mail: lukasz.gawel@uj.edu.pl

\title{
Strategie marketingowe w muzeach ${ }^{1}$
}

Abstract

\section{Marketing Strategies in Museums}

Many Polish museums have yet to discover and claim their position in the broader social context. All too often, their activity is in no way related to the needs, expectations, and aspirations of the visitors. This state of affairs is caused first and foremost by the attitude of suspicious aversion towards marketing strategies, with the latter being perceived as an element of a market-driven game characteristic to the business sector which, in turn, is commonly associated with dishonesty and objectives standing in stark contrast to public cultural institutions' mission. This article delineates the actual significance of marketing strategy in museums by presenting the effects of their lacking in interest in own auditoriums' needs.

Keywords: museum, marketing strategies, auditorium, marketing in museums

Słowa kluczowe: muzeum, strategie marketingowe, audytorium, marketing w muzeach

\section{Nprowadzenie}

Polskie muzea po 1989 roku przeszły głęboką metamorfozę. Zmieniło się wiele obszarów ich działania (np. wprowadzenie systemów cyfrowego wsparcia zarządzania finansami i kadrami), powstały również nowe instytucje z nowoczesnymi ekspozycjami o narracyjnym charakterze, między innymi Muzeum Emigracji w Gdyni, Muzeum

${ }^{1}$ Niniejszy artykuł jest rozszerzoną i uzupełnioną wersją tekstu drukowanego w: Ł. Gaweł, F. Skowron, A. Szostak, Raport z projektu badawczego „Krakowski Odbiorca Kultury”, Wydawnictwo Attyka, Kraków 2019. 
II Wojny Światowej w Gdańsku czy Polin w Warszawie. W tych nowo powstających instytucjach zatrudniano całkowicie nowe zespoły, co umożliwiło skokowy postęp w zakresie kultury zarządczej względem innych muzeów, funkcjonujących niejednokrotnie od dziesięcioleci. W tych zespołach nierzadko znajdują się osoby pracujące w jednym muzeum od 20 czy 30 lat, które nigdy nie miały okazji poznać innej kultury organizacyjnej, nigdy również nie musiały zmierzyć się z realiami rynku pracy. Nic więc dziwnego, że w wielu obszarach występuje tam olbrzymi opór przed wszelkimi zmianami. Do tych obszarów bez wątpienia zaliczyć należy szeroko pojęty marketing.

Peter Drucker, tworząc listę warunków, które czynią zarządzanie skutecznym, podał siedem zasad, spośród których jedna mówi, że „zarządzanie musi być zorientowane przede wszystkim na najistotniejszy, podstawowy i ostateczny rezultat - zadowolenie klienta" [za: Jemielniak, Latusek-Jurczak 2014]. Okazuje się, że to, co jest absolutnie podstawą działania każdej organizacji biznesowej, w świecie muzeów niekoniecznie jest w ogóle zrozumiałe. Jest to bez wątpienia obszar, który musi zostać poddany badaniom i szczegółowej analizie. Zważywszy na fakt, że w Polsce funkcjonuje kilkaset muzeów publicznych, których organizatorem są samorządy (gminne, powiatowe lub wojewódzkie) lub ministerstwo kultury i dziedzictwa narodowego, z których największe otrzymują kilkadziesiąt milionów złotych dotacji, konieczne jest określenie, jakie powinności w kontekście relacji z odbiorcami powinny spełniać te instytucje. Organizatorzy muzeów nie definiują oczekiwań w tym obszarze, choć bez wątpienia niektórzy doceniają rolę i znaczenie nowocześnie pojmowanego marketingu. Przykładem tego może być szkolenie z zakresu marketingu muzeów, zorganizowane przez Departament Dziedzictwa Kulturowego Ministerstwa Kultury i Dziedzictwa Kulturowego dla muzeów narodowych i współprowadzonych, zorganizowane w Europejskim Centrum Solidarności w Gdańsku w 2017 roku, a następnie w Warszawie wspólnie z polskim oddziałem Facebooka w roku 2019.

\section{Literatura przedmiotu}

Obecnie dostępnych jest dziesiątki opracowań poruszających problematykę marketingu muzeów, $\mathrm{z}$ tego wiele zostało w całości poświęconych temu zagadnieniu. Jedną z najważniejszych publikacji, które ukazały się na polskim rynku wydawniczym, zmieniającym sposób patrzenia na muzea, była wydana w 2006 roku książka Geralda Matta. Chociaż w spisie treści tej publikacji na próżno będziemy szukali terminu "marketing”, to cała ta publikacja jest przesycona myśleniem o odbiorcy, poznawaniem go, badaniem jego potrzeb. Pisząc o strategicznych decyzjach odnoszących się do usytuowania muzeów w przestrzeni instytucji kultury, Matt zadaje na przykład takie pytania: 
Do jakich grup publiczności adresowana jest działalność muzeum; czy prowadzący ją ludzie mają świadomość zainteresowań, motywacji, poziomu wykształcenia zwiedzających, których chcą pozyskać? Czy oferowane propozycje programowe dostosowane są do wybranych grup „docelowych”? Jak zapewnić skuteczność wyboru takich grup? [Matt 2006: 22-23].

Mimo że od premiery cytowanej książki upłynęło już kilkanaście lat, tematyka marketingu w muzeach przebija się do literatury z trudem, przywoływana w nielicznych tekstach [Gaweł 2012; Misiak 2014]. Próżno na przykład szukać opracowania tak kompletnego jak sygnowana między innymi przez Philipa Kotlera książka Museum Marketing \& Strategy [Kotler, Kotler, Kotler 2008]. Co więcej, można odnieść wrażenie, że dla klasycznych muzealników sam termin nie jest rozpoznany, a znaczenie marketingu w pracy muzeów traktowane jest pobieżnie, wyraźnie widać, że zarówno kwestie marketingu, jak i samego zarządzania są im po prostu obce. Widać to wyraźnie na przykład w tekście Andrzeja Rottermunda o znaczącym tytule Muzea - perspektywy. Pisząc o przyszłości muzeów, definiuje on w siedmiu punktach prognozy dotyczące przyszłości muzeów. Dopiero piąty z nich zawiera interesujące nas treści, przy czym brzmi on następująco:

Muzea publiczne, pod wpływem impulsów ze strony gospodarki rynkowej i dynamiki muzeów prywatnych, przyjmą bardziej funkcjonalne sposoby zarządzania, finansowania i gospodarowania majątkiem muzealnym, a w obliczu nowych form komunikacji społecznej przebudują swoje komórki odpowiedzialne za działania marketingowe [Rottermund 2015: 5].

Co ciekawe, w punkcie 1 znalazła się wzmianka o edukacji muzealnej, ale opisywanej bez kontekstu odbiorców, ich potrzeb, pragnień czy aspiracji. Tymczasem to właśnie odbiorca (czy też szerzej: otoczenie społeczne) stał się podstawowym punktem odniesienia w najnowszych publikacjach poświęconych muzeom [Lord, Lord 2009; Black 2012; Piontek 2017].

Ten pobieżny przegląd dostępnej literatury tematu, pozwala zdiagnozować obecne w polskich muzeach rozwarstwienia, występujące na różnych polach. Pierwszym jest dysonans pomiędzy nauką a praktyką - dostępne teksty, głównie zachodnie, nie są wykorzystywane w pełni w praktyce zarządzania polskimi instytucjami muzealnymi. Wynika to z drugiego rozwarstwienia, występującego w samych zespołach muzealnych: wyraźnie podzieliły się one na zwolenników budowania relacji, poznawania, badania i odpowiadania na potrzeby odbiorców (poza działami marketingu są to również działy edukacji, obsługi klienta, nierzadko wydawnictwa muzealne) oraz zatwardziałych zwolenników „dawnego” modelu, w którym dochodzi do swoistej absolutyzacji przedmiotu i niemal całkowitego odrzucenia wejścia w głębszy dialog z odbiorcami (duża część kustoszy). To z tego powodu w największych polskich muzeach, przygotowując wystawę z kilkusettysięcznym budżetem, kurator-kustosz może sobie pozwolić na publiczne wyrażenie opinii, że on „nie robi tej wystawy dla odbiorców”. 


\section{Netodologia}

Niniejszy tekst powstał dzięki trzem grupom źródeł. Pierwsze są związane z pracą autora, pełniącego w latach 2016-2019 funkcję zastępcy Dyrektora Muzeum Narodowego w Krakowie ds. Strategii, Rozwoju i Komunikacji. Drugie to dane jakościowe (podobnie jak w pierwszym przypadku) zebrane podczas dziesięcioletniej działalności w roli eksperta zewnętrznego, współpracującego z kilkunastoma różnorodnymi instytucjami muzealnymi.

Opisana powyżej sytuacja wydaje się idealnie pasować do nowej praktyki w obszarze metodologii badań jakościowych, określanej w literaturze anglojęzycznej mianem reflexive [zob. Hibbert, Sillince, Diefenbach, Cunliffe 2014; Cunliffe 2016] (...). Poszukując polskiej nazwy opisanej w przywołanych wyżej artykułach anglojęzycznych metody badawczej, doszedłem do wniosku, że adekwatnym terminem będzie: relacyjna metoda interpretatywna [Gaweł 2018: 23].

Trzecia grupa danych ma charakter ilościowy i została zebrana podczas realizacji projektu badawczego „Krakowski odbiorca kultury”, realizowanego w latach 2017-2019, którego autor był kierownikiem.

\section{Relacje muzeów $z$ otoczeniem spolecznym}

Obserwując praktykę zarządzania polskimi muzeami publicznymi, można wskazać trzy typy instytucji. Choć wydaje się, że powinny one odzwierciedlać historyczny rozwój publicznych instytucji kultury w kontekście ich funkcjonowania w otoczeniu społecznym, wciąż występują jednocześnie w perspektywie polskiego sektora kultury.

Pierwszy model funkcjonowania określam mianem muzeum wsobne - nastawione w istocie na trwanie, bez perspektywy rozwoju w zakresie relacji z otoczeniem. Program merytoryczny instytucji kreowany jest w oderwaniu od realnych potrzeb czy oczekiwań otoczenia, które w niewielkim tylko stopniu bywa informowane o prowadzonej działalności. Muzea tego typu sięgają jedynie po utarte kanały komunikacji, nie szukają nowych dróg porozumienia, nie mają potrzeby zdobywania wiedzy na temat swoich odbiorców. Takie hermetyczne instytucje coraz rzadziej spotykamy wśród dużych instytucji kultury, ale wciąż są obecne w sektorze kultury, zresztą nie tylko w świecie muzeów. Zarówno zarząd tych organizacji, jak i ich pracownicy nie wiążą tej postawy ze swoją przyszłością. Funkcjonowanie w otoczeniu społecznym muzeów tego typu zostało przedstawione graficznie na rysunku 1. 


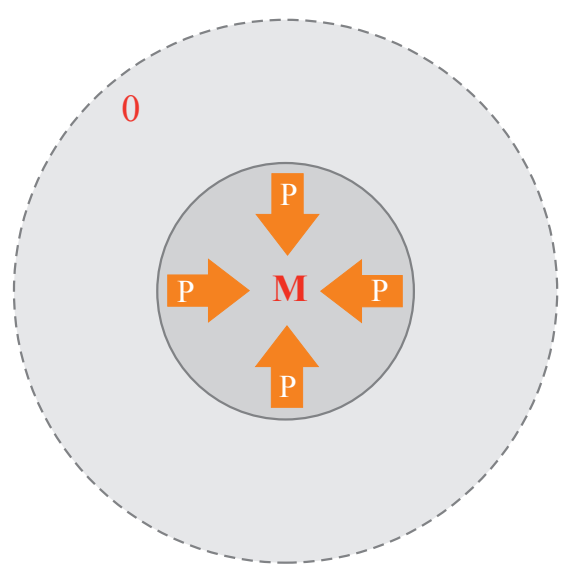

Rysunek 1. Muzeum w otoczeniu społecznym - muzeum wsobne (M - muzeum, $\mathrm{P}$ - program merytoryczny, $\mathrm{O}$ - otoczenie społeczne)

Źródło: opracowanie własne.

Drugi typ jest najpowszechniej obecnie występujący. Jest to muzeum otwarte, szukające porozumienia z otoczeniem, szeroko informujące o prowadzonej działalności, wykorzystujące różne kanały informacji. Oferta tego typu muzeów jest różnorodna i nie skupia się jedynie na działalności wystawienniczej. Wystawom towarzyszy zazwyczaj bogaty program edukacyjny (oprowadzania kuratorskie, lekcje muzealne, odczyty i wykłady, warsztaty itp.); ponadto oferta tego typu instytucji obejmuje różnego rodzaju aktywności, które nie są typowe dla tradycyjnych muzeów, takie jak koncerty, projekcje filmowe czy spotkania autorskie. Bardzo często muzea tego typu mają dobrze zaopatrzony sklep muzealny, w którym można nabyć nie tylko wydawnictwa i gadżety związane z bieżącą ofertą wystawienniczą; oferta sklepu obejmuje zarówno książki oraz innego rodzaju publikacje szeroko związane z charakterem muzeum, jak i nowości wydawnicze. Tym sposobem pojawia się kolejny powód odwiedzenia placówki. Z tego samego powodu duże znaczenie przywiązuje się do jakości oferty działającej na terenie muzeum kawiarni. W ten sposób muzea poszerzają stale swoje audytorium, starając się budować społeczność stale obecną w instytucji, znajdującą różne powody przychodzenia tutaj. W obszarze działalności promocyjnej pojawiają się wysokiej klasy projektowej materiały służące komunikacji wizualnej, jak również doskonale przygotowane całe kampanie promocyjne czy materiały audiowizualne. Dobrym przykładem tego typu działań jest na przykład kampania promocyjna $\mathrm{Mu}$ zeum Narodowego w Warszawie z udziałem ambasadorów Muzeum, którymi zostali Marcin Gortat, Monika Brodka oraz Marek Kamiński [https://www.mnw.art.pl/ wizyta/a-ty-co-zobaczysz/ambasadorzy/, odczyt: 20.02.2020] czy kanał na platformie YouTube Przeszłość przyszłości [https://www.youtube.com/watch?v=tllTKgFiFE4\&list =PLqfyjXfxSQ5uwtWQJ6BXUjbarcjeUNafG, odczyt: 20.02.2020], na którym można 
oglądać krótkie filmy, między innymi ten, w którym dyrektor Muzeum Narodowego w Krakowie Andrzej Betlej opowiada o najcenniejszych eksponatach z kolekcji Muzeum Książąt Czartoryskich, budując w ten sposób narrację poprzedzającą ponowne otwarcie Muzeum Czartoryskich po trwającym wiele lat remoncie.

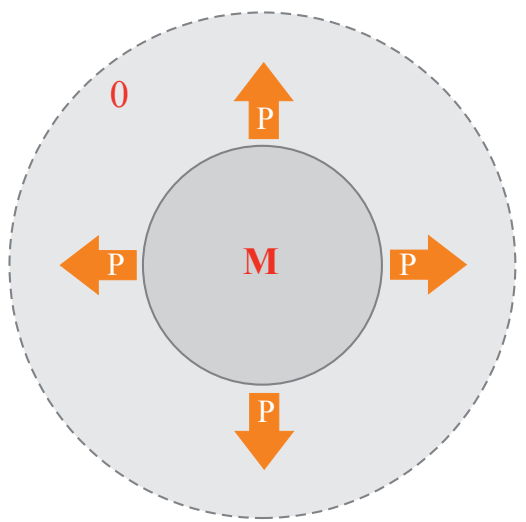

Rysunek 2. Muzeum w otoczeniu społecznym - muzeum otwarte ( $\mathrm{M}$ - muzeum, $\mathrm{P}$ - program merytoryczny, O - otoczenie społeczne)

Źródło: opracowanie własne.

Pozornie wydaje się, że model przedstawiony na rysunku 2 nie ma wad, prawda jest jednak taka, że muzea $\mathrm{z}$ jednej strony walczące $\mathrm{z}$ coraz większą konkurencją w zakresie oferty zarządzania czasem wolnym, z drugiej zaś - utrzymywane ze środków publicznych, muszą wchodzić w znacznie głębsze relacje z otoczeniem społecznym, stając się muzeami społecznie zaangażowanymi. Aby do tego doszło, muzea muszą wejść w autentyczną relację z odbiorcami, muszą poznać, kim oni są, jakie są ich oczekiwania, aspiracje, potrzeby, jakie mają kompetencje kulturowe, jakie mają wykształcenie, z jakiej oferty kulturalnej korzystają i jak często to robią, czy przychodzą do muzeum sami, czy w towarzystwie itd. Innymi słowy muzea pragnące rzeczywiście budować trwałe relacje $\mathrm{z}$ otoczeniem muszą wdrożyć program stałych i powtarzalnych badań swoich odbiorców; i to nie tylko badań ilościowych, ale także jakościowych. Choć zabrzmi to jak truizm, same badania są tyko pierwszym krokiem. Konieczna jest nie tylko ich profesjonalna analiza i opracowanie, ale przede wszystkim autentyczne włączenie uzyskanych wyników w prowadzony proces zarządzania zmianą. Okazuje się, że często właśnie ten ostatni etap jest największą słabością wielu instytucji kultury. Strategie marketingowe i zarządzanie relacjami $\mathrm{z}$ otoczeniem społecznym są bowiem nierzadko postrzegane jako cyniczna manipulacja, której absolutnie nie mogą podlegać publiczne instytucje kultury.

Trudno mieć żal, że refleksja nad znaczeniem marketingu w działalności publicznych instytucji kultury w Polsce (podobnie jak i w innych krajach dawnego bloku 
sowieckiego) nie ma tak długiej tradycji. W latach sześćdziesiątych XX wieku działały one w realiach państwa socjalistycznego. Nie można jednak wciąż tłumaczyć takiego stanu rzeczy, skoro od zmiany ustrojowej z roku 1989 minęło już 30 lat. Tymczasem niechęć do myślenia o realiach otoczenia w kontekście konkurencyjności, konieczności walki o odbiorcę, szukania nowych form kontaktu z nim jest wciąż obecna wśród wielu (większości?) pracujących w publicznych instytucjach kultury. Co zaskakujące, potwierdzające tę diagnozę stwierdzenia można usłyszeć nie tylko podczas rozmów z pracownikami różnego typu instytucji kultury, ale odnajdujemy je również - jeśli tak można powiedzieć - w oficjalnych materiałach służących rozwojowi tego sektora. W 2013 roku przez Bibliotekę Elbląską realizowany był projekt pod nazwą „Jak uniknąć samotnej gry w kręgle w obszarze kultury. W poszukiwaniu remedium na międzyinstytucjonalne i międzysektorowe bariery budowania kapitału społecznego w środowisku kultury lokalnej”. Na stronie internetowej projektu umieszczono materiały edukacyjne, a wśród nich prezentację zatytułowaną „Jak instytucje kultury mogą wykorzystywać metody marketingowe? Inspiracje i ćwiczenia”. Trzeci slajd tego materiału szkoleniowego zawiera następujące treści: „Co myślimy o marketingu w instytucjach publicznych i organizacjach pozarządowych? Temat płytki i przegadany. Podejście właściwe dla korporacji i ich stylu działania a przez to: nieuczciwe, trudne, oparte na manipulacji, podejście pozbawione wartości i emocji..., a zatem niezgodne z misją instytucji publicznych i NGO!" [http://ahttp://antybowling.bibel. pl/pakiet.phpntybowling.bibel.pl/pakiet.php, odczyt: 20.02.2020].

Niestety autor tego materiału pozostał anonimowy, nie sposób więc stwierdzić, czy pracuje w publicznym sektorze kultury. Chciałbym wierzyć, że nie... Przytoczona wypowiedź jest bowiem nie tylko w całości zbudowana na stereotypach dotyczących sektora biznesowego, powierzchownej ocenie strategii marketingowych, ale jest również przesycona poczuciem wyższości, nie tak trudnym do odnalezienia wśród osób pracujących w publicznych instytucjach kultury. To temat na osobny tekst, ale pogłębianie rzekomej przepaści pomiędzy idealistami z sektora publicznego i bezmyślnymi sybarytami z sektora komercyjnego nikomu nie służy, na pewno nie przyczynia się do rozwoju publicznych instytucji kultury. Są one przecież otwarte dla wszystkich - również dla pracowników tych „strasznych korporacji”. Prawda jest taka, że wywołują oni niepewność, wnoszą niespodziewane zamieszanie, przychodząc ze świata często nieznanego pracującym w publicznym sektorze kultury. Stąd taka łatwość w sięganiu po stereotypy i uproszczenia. Sytuację tę doskonale zdiagnozowały już kilka lat temu Krystyna Mazurek-Łopacińska oraz Magdalena Sobocińska:

Cechą współczesnego otoczenia rynkowego instytucji kultury jest rosnąca złożoność oraz szybkość zmian, które w konsekwencji sprawiają, że zwiększa się niepewność działania. Ponadto coraz trudniej jest przenieść lub wprost zastosować zdobyte wcześniej doświadczenia w nowych sytuacjach na rynku kultury [Mazurek-Łopacińska, Sobocińska 2011: 75]. 
To bez wątpienia doskonała diagnoza, ale niestety nie niesie z sobą nadziei... Dynamicznie zmieniające się otoczenie, zmiany technologiczne, coraz większa, konkurencyjna oferta zarządzania czasem wolnym, rosnące oczekiwania audytorium, przyzwyczajenie do wysokich standardów obsługi - wszystko to są bez wątpienia obiektywne trudności, ale w żaden sposób nie wpłyną one na poprawę kondycji publicznych instytucji kultury. Może to brzmieć paradoksalnie, ale muszą sobie poradzić z nimi tak samo, jak radzą sobie... organizacje biznesowe, owe napiętnowane korporacje. Może warto w tym miejscu zauważyć, że - jak większość organizacji - tak i korporacje nie mają jednego oblicza. Bywają lepsze, bywają gorsze. Jedno wiadomo o nich na pewno - wiele z nich powstało w Europie Zachodniej oraz Stanach Zjednoczonych w warunkach stabilnych demokracji, wiele ma za sobą dziesiątki lat rozwoju, a to oznacza, że ich kultura organizacyjna, nawet jeśli nie idealna, bez wątpienia warta jest analizy, warta zainteresowania w kontekście procesu transformacji publicznych instytucji kultury.

W tym kontekście bezsensowne jest pytanie, jakie wyzwania zmieniająca się rzeczywistość stawia przed współczesnymi muzeami. Prawda jest taka, że muzea nie muszą się zmieniać ze względu na zmieniające się otoczenie społeczne. One po prostu są częścią tego środowiska, więc zmiany są naturalne i nie wypływają z chęci „dostosowania się do wymogów współczesności”, ale z naturalnego procesu zmiany rzeczywistości, w której żyjemy. Właściwa jest więc odwrotna perspektywa: muzea, które nie ulegają zmianie, nie ewoluują, stają się obcą strukturą, nienaturalną w otoczeniu, z którego wyrosły (rysunek 3).

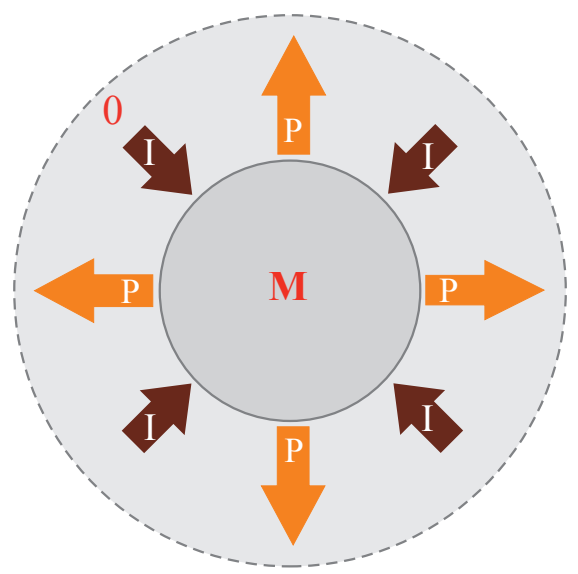

Rysunek 3. Muzeum w otoczeniu społecznym - muzeum społecznie zaangażowane ( $M$ - muzeum, P - program merytoryczny, I - informacja na temat odbiorców oferty, O - otoczenie społeczne)

Źródło: opracowanie własne. 


\section{Marketing w muzeach}

W kontekście tego, co napisano powyżej, marketing w muzeach jest nieodzownym narzędziem zarządzania strategicznego, który musi być traktowany tak samo, jak we wszystkich organizacjach rynkowych. Sens tego współcześnie uprawianego marketingu doskonale oddał Łukasz Burkiewicz:

Początkowo rozwój marketingu obejmował sferę produkcji dóbr konsumpcyjnych i przemysłowych, jednak szybko przedostał się do sektora organizacji non-profit, a następnie do kultury. Zasadniczo marketing jest ściśle związany z zarządzaniem, a Philip Kotler, uchodzący obecnie za najważniejszego specjalistę w dziedzinie marketingu, mówi o nim jako o procesie zarządzania, podkreślając, że jest to coś więcej niż tylko sprzedaż i reklama, walcząc w ten sposób z powszechnym utożsamianiem marketingu tylko i wyłącznie z reklamą. Marketing jest m.in. procesem społecznym, dzięki któremu jednostki lub grupy otrzymują to, czego potrzebują i chcą, poprzez kreowanie, oferowanie i swobodną wymianę produktów i usług [Burkiewicz 2014: 165].

Jak wynika z tej oceny, marketing nie tylko nie stoi na drodze misyjnej działalności publicznych instytucji kultury, ale wręcz staje się szansą dla pełnej realizacji misji. W jaki bowiem inny sposób instytucje te mogą kreować rynek usług kulturalnych? Stwarzać potrzeby swoich odbiorców? Czynić ich świadomymi podejmowanych wyborów? Marketing jest w istocie potężnym narzędziem budowania relacji, kreowania potrzeb; aby było to możliwe, konieczne jest jednak otwarcie się na odbiorcę, wsłuchanie w jego potrzeby, wejście w autentyczny dialog bez poczucia zagrożenia, że współpraca z odbiorcami może zagrozić pozycji pracowników instytucji kultury. Marketing może się wreszcie stać medium komunikowania i kreowania wartości kluczowych dla instytucji kultury, te zaś należy traktować „(...) jako podstawę dla rozwoju bliższych relacji [z odbiorcami - przyp. Ł.G.]. Należy oprzeć się na tym rdzeniu, budować z niego nowe treści i działania - zarówno realne, jak i wirtualne które spełnią określone potrzeby, wspierając regularne zaangażowanie odbiorców" [Black 2012: 52; tłum. Ł.G.].

Jak zrealizować ten - jak wydawałoby się z opisu - prosty plan? Wbrew pozorom nie jest to łatwe zadanie, wymaga bowiem odrzucenia wielu przyzwyczajeń i uprzedzeń oraz zwrócenia się do sprawdzonych zasad klasycznego marketingu czy też marketingu dedykowanego sektorowi publicznemu. Zagadnieniu temu odrębną publikację poświęcili Philip Kotler i Nancy Lee [zob. Kotler, Lee 2008].

Kwestią zasadniczą pozostaje skupienie uwagi na odbiorcy, które musi się stać podstawą każdego działania. Tymczasem brak zainteresowania odbiorcą leży u podstaw wielu nieporozumień i porażek w sektorze kultury (nawet instytucje artystyczne muszą brać pod uwagę relację z odbiorcami - teatr, filharmonia czy opera mogą być programowo niezainteresowane umasowieniem swojego „produktu”, 
niemniej jednak nawet one muszą zdobyć określoną grupę odbiorców, która będzie motywowała sens ich działania). W polskich warunkach wydaje się to szokujące, ale na świecie działają muzea, w których praca nad wystawą zaczyna się od dialogu z odbiorcami, zbadania ich potrzeb, marzeń, aspiracji, zapytania o preferencje w zakresie realizowanej ekspozycji.

National Museum Wales (National Museums and Galleries of Wales), składające się z siedmiu walijskich muzeów, wypracowało Community Engagement Strategy na lata 2015-2020. W pierwszym rozdziale tego dokumentu możemy przeczytać między innymi, że:

strategia i związany z nią plan działania będą opierać się na dotychczasowych sukcesach, ale mają zapewniać bardziej strategiczne podejście do zagadnienia pracy na rzecz społecznego zaangażowania, co ma pomóc muzeum w:

- priorytetowym traktowaniu pracy oraz lepszym wykorzystaniu dostępnych zasobów;

- ustaleniu spójnego podejścia oraz określeniu ram społecznego zaangażowania;

- maksymalizowaniu potencjału zaspokajania potrzeb i aspiracji społeczności;

- podtrzymywaniu relacji i budowaniu kluczowych partnerstw skoncentrowanych na poszczególnych obszarach pracy;

- opieraniu pracy na bieżących badaniach oraz wiedzy zdobywanej w wyniku realizacji kluczowych projektów;

- rozwijaniu kompetencji oraz specjalistycznej wiedzy pracowników w tym obszarze pracy [http://ourmuseum.org.uk/wp-content/uploads/Community-Engagement-Strategy-2015-20-1.pdf, odczyt: 20.02.2020, tłum. Ł.G.].

Tak szeroko zakrojone działania na rzecz partycypacji w obszarze zarządzania publicznymi instytucjami kultury w Polsce wydają się być trudne do wyobrażenia. Wystarczy jednak lepiej przyjrzeć się mapie polskich instytucji kultury, aby zrozumieć, że nie tylko nie jest to możliwe, ale że niektóre instytucje kultury podążają podobną drogą. Bez wątpienia należy do nich Dom Kultury INSPIRO w podkrakowskim Podłężu, prowadzony co prawda przez stowarzyszenie, ale będący samorządową instytucją kultury.

Działalność INSPIRO znakomicie ukazuje ową zmianę myślenia, powolne przekształcanie się MY w WY. Otóż na początku Beata i Maciek organizowali zajęcia tam, gdzie ich przyjęto, nie myśleli o lokalu czy stałym adresie. Poszczególne inicjatywy sprawiały im dużo radości, chcieli po prostu działać. Potrzeba przekształcenia „bezdomu” w dom w pierwszej kolejności pojawiała się wśród ludzi przychodzących na zajęcia. Ciągłe przemieszczanie się INSPIRO utrudniało stały kontakt, a tego oczekiwała część odbiorców. Pojawił się więc pomysł, by spróbować gdzieś osiąść. Początkowo była to spiżarka w domu rodzinnym Beaty, z czasem pokoik w budynku Domu Kultury w Podłężu a ostatecznie przekazana pod opiekę cała instytucja. Co istotne, założyciele Stowarzyszenia nie szukali dla siebie etatu, nie prosili o funkcje dyrektora 
czy kierownika. Nie chcieli domu kultury, lecz w domu kultury chcieli mieć INSPIRO - nie narzucając rozwiązań woleli odpowiadać na potrzeby. (...). To, co dzieje się w INSPIRO, jest unikalne nie ze względu na formę prawną, typ zajęć czy liczbę uczestniczących w nich osób ale na fakt, że Beacie i Maćkowi udało się stworzyć w tym miejscu specyficzną społeczność, która funkcjonuje na bardzo określonych zasadach: wolności i równości. Zasady te - być może patetycznie brzmiące, a w dyskursie społecznym często nadużywane - stanowią istotę i podstawę tego miejsca, przekształcając je w autentyczną sferę publiczną [Zdebska-Schmidt 2017; odczyt: 23.02.2019].

Działaniem koniecznym w obszarze skutecznego marketingu jest także „segmentacja klientów i indywidualizacja usług" [Kotler, Lee 2008: 15]. Takie podejście do odbiorcy oferty kulturalnej często budzi niechęć, a koronnym argumentem w tym kontekście staje się deklaracja mówiąca o tym, że „nasza oferta jest dla wszystkich". To oczywiście do pewnego stopnia prawda - wystawa muzealna jest przecież (w zdecydowanej większości przypadków) dedykowana dla różnych grup odbiorców, różnych pod względem wieku, ale też kompetencji kulturowych czy merytorycznych. Sęk w tym, że to ogólne założenie nie zmienia konieczności myślenia o różnych grupach odbiorców od pierwszych prac koncepcyjnych. Odbiorcy muszą być „wdrukowani” w projekt od samego początku jego realizacji, w samą istotę jego tworzywa; nie sposób nawiązać autentycznej relacji z odbiorcami, jeśli zaczyna się o nich myśleć dopiero po zakończeniu pracy (na przykład nad muzealną wystawą).

Konieczne jest również „myślenie odbiorcą” w kontekście ogólnej koncepcji działania instytucji. Każdy z odwiedzających jest nieco inny, każdy niesie z sobą inne wyobrażenie „idealnych odwiedzin” w teatrze, filharmonii czy muzeum. Stąd tak ważne jest indywidualizowanie usług, otwartość na zaspokajanie różnego rodzaju oczekiwań i potrzeb - to dlatego tak gwałtownym zmianom ulegają biblioteki - ich pracownicy coraz częściej nie zmuszają już użytkowników czytelni do zasiadania na twardych krzesłach przy blatach; mogą oni wybrać miękką sofę lub pufę, nierzadko udając się na swoje miejsce z kubkiem kawy czy herbaty. Zmienia się na przykład również sposób dystrybucji biletów w muzeach - coraz częściej można skorzystać ze zindywidualizowanej oferty łączenia różnych biletów, uprawniających do wstępu w różne przestrzenie muzealne w różnym czasie.

To skupienie na odbiorcy Kotler opisuje w interesujący sposób, podkreślając prostą zasadę - odbiorca/widz, który decyduje się na odwiedziny publicznej instytucji kultury, musi mieć jasną wizję tego, co zyska, jaką korzyść przyniesie ta wizyta:

Szybkim sposobem zrozumienia. o co chodzi w skupianiu uwagi na klientach, jest przyjęcie założenia, że twój klient (docelowa publiczność) nieustannie zadaje pytanie: „Co ja z tego będę miał?”. Często określa się to jako zjawisko (...) WIFM - „What's in it for me”. (...) skuteczni menedżerowie marketingu nieustannie dążą do lepszego (...) zrozumienia i zaspokojenia pragnień oraz potrzeb (...) klientów [Kotler, Lee 2008: 23, tłum. Ł.G.]. 
W tym kontekście bardzo dużego znaczenia nabiera kolejny wyznacznik dobrego marketingu - analizowanie oferty konkurencji. Wyrażane niekiedy przekonanie, że publiczne instytucje kultury nie konkurują z sobą, całkowicie nie koresponduje z ich faktycznym statusem, funkcjonowaniem w otoczeniu. Publiczne instytucje kultury konkurują zarówno w zakresie kapitału ludzkiego, jak i zasobów finansowych (środki publiczne). Świadomość konkurencyjności czy też świadomość konieczności sprostania konkurencji musi stać się stałą w myśleniu o przyszłości każdej instytucji kultury. Tym bardziej że zmiana myślenia na ten temat widoczna jest od lat w wypowiedziach niektórych decydentów kreujących porządek rzeczywistości publicznych instytucji kultury. Dowodem tego mogą być słowa Krzysztofa Markiela, dyrektora Departamentu Kultury i Dziedzictwa Narodowego w Urzędzie Marszałkowskim Województwa Małopolskiego, wypowiedziane podczas debaty zorganizowanej przez Instytut Kultury Uniwersytetu Jagiellońskiego. Na pytanie „Czy powinno się zrównać prawa instytucji i organizacji pozarządowych do konkurowania o te same środki publiczne?", dyrektor Markiel odpowiedział:

Nazwałbym to rozbijaniem monopolu, aby było lepiej. Powinniśmy bardziej wspierać inicjatywy i celowe programy, a nie przede wszystkim poszczególne publiczne instytucje. Dlatego nie chciałbym, żeby podstawowa metodologia i uwaga skupiała się, jak obecnie, tylko na sposobach i instrumentach polityki kulturalnej związanych z planowaniem, regulowaniem oraz finansowaniem istniejących struktur. Same instytucje mają tego świadomość [ $C z y$ kultura musi bać się... 2014].

Takie podejście do sektora publicznego w polskich realiach wypada uznać za rewolucyjne, ale skoro pojawia się takie myślenie - które na Zachodzie Europy od wielu lat jest obowiązującą praktyką - oznacza to, że publiczne instytucje kultury muszą przygotować się na zmiany. W takim razie jednak marketing jest nie tylko wymogiem w kontekście dotrzymywania kroku na konkurencyjnym rynku, budowania relacji z odbiorcami, ale również jedyną drogą na zapewnienie bezpiecznej przyszłości organizacji...

Pisząc o nastawieniu marketingowym organizacji sektora publicznego, Kotler i Lee postulują także wprowadzenie zasady monitorowania działań i wyprowadzania korekt. Ten postulat wpisuje się doskonale w definicję organizacji uczącej się, a więc zdolnej do modyfikowania swoich zachowań w wyniku pozyskiwanej wiedzy i nabywanego doświadczenia. Aby to było możliwe, publiczne instytucje kultury muszą osiągnąć stosunkowo wysoki poziom autorefleksji, zainteresowania samymi sobą, krytycznej analizy własnych poczynań. Musi to być poparte systemowym zdobywaniem danych, badaniem odbiorców, analizowaniem procesów realizowanych w organizacji. Żeby to miało sens, działaniem prymarnym musi być zdefiniowanie jasnych celów, do których się dąży. 


\section{Podsumowanie}

Przedstawiony powyżej pobieżny przegląd zagadnień związanych z marketingiem w muzeach uświadamia, że jest on nie tyle jedną z możliwych dróg, ile warunkiem niezbędnym dla zbudowania nowoczesnej instytucji budującej trwałe związki ze swoim audytorium. American Marketing Association (Amerykańskie Stowarzyszenie Marketingu) zdefiniowało marketing jako „funkcję organizacyjną i zbiór procesów tworzenia, komunikowania klientom i dostarczania im wartości oraz zarządzania relacjami z klientami w sposób przynoszący korzyści organizacji i jej interesariuszom" [Kotler, Lee 2008: 37]. Szczególnie istotna wydaje się końcówka tej definicji - marketing jest procesem dwukierunkowym, nie może być traktowany jedynie jako mechaniczny sposób nakłaniania klienta do nabycia towaru lub usługi. Marketing w nowoczesnych organizacjach kultury służy im samym i klientom, jest dwustronną relacją pozwalającą wzrastać i rozwijać się jednej, jak i drugiej stronie.

\section{Bibliografia}

\section{Publikacje}

Black G. (2012), Transforming Museums in the Twenty-First Century, London-New York: Routledge.

Burkiewicz $Ł$ (2014), Marketing $w$ kulturze. Ukierunkowanie na rynek czy na produkt, „Perspektywy Kultury" nr 2. s. 161-173.

Czy kultura musi bać się słowa konkurencja? „Dziennik Polski”, 21.01.2014, https://dziennikpolski24.pl/czy-kultura-musi-bac-sie-slowa-konkurencja/ar/3304276/5 [odczyt: 5.02.2019].

Gaweł Ł. (2012), Kreowanie wizerunku, budowanie relacji. Przyczynek do zarzadzania muzeum, [w:] A. Kowalska (red.), Muzeum w świetle reflektorów, Kraków: Muzeum Historyczne Miasta Krakowa, s. 96-102.

Gaweł Ł. (2018), Zaginiony świat - edukacja muzealna jako kluczowy komponent procesu zarzadzania dziedzictwem kulturowym, [w:] Ł. Gaweł, M. Kostera (red.), Etnografie instytucji dziedzictwa kulturowego, Kraków: Wydawnictwo Uniwersytetu Jagiellońskiego, s. 17-31.

Jedlewska B. (2006), Marketing $w$ działalności podmiotów kultury - aktualne wyzwania, problemy i doświadczenia, „Zarządzanie w Kulturze”, t. 7, s. 95-106.

Jemielniak D., Latusek-Jurczak D. (2014), Zarządzanie. Teoria i praktyka w pigułce, Warszawa: Wydawnictwo Poltext.

Kaleta K. (2003), Marketing kultury i jego specyfika, „Marketing i Rynek”, nr 10, s. 14-20.

Kotler N.G., Kotler Ph., Kotler W.I. (2008), Museum Marketing \& Strategy: Designing Missions, Building Audiences, Generating Revenue and Resources, San Francisco: Jossey-Bass.

Kotler Ph., Lee N. (2008), Marketing w sektorze publicznym. Mapa drogowa wyższej efektywności, tłum. A. Ehrlich, Warszawa: Wydawnictwa Akademickie i Profesjonalne, Wyższa Szkoła Przedsiębiorczości i Zarządzania im. Leona Koźmińskiego. 
Lord G.D., Lord B. (2009), The Manual of Museum Management, Lanham-New York-TorontoPlymuth: AltaMira Press.

Matt G. (2006), Muzeum jako przedsiębiorstwo, Aletheia, Warszawa.

Mazurek-Łopacińska K., Sobocińska M. (2011), Rola marketingu w rozwoju usług kulturalnych, „Problemy Zarządzania, Finansów i Marketingu”, nr 18, s. 75-85.

Misiak J. (2014), Muzeum jako organizacja usługowa, [w:] M. Szeląg (red.), Raport o stanie edukacji muzealnej. Suplement. Cz. 1, seria „Muzeologia”, t. 8, Kraków: Towarzystwo Autorów i Wydawców Prac Naukowych Universitas; Warszawa: Muzeum Pałacu Króla Jana III w Wilanowie, s. 8-18.

Piontek A. (2017), Museum und Partizipation: Theorie und Praxis kooperativer Ausstelungsprojekte und Beteiligungsangebote, Bielefeld: Transcript Verlag.

Rottermund A. (2015), Muzea - perspektywy, „Muzealnictwo”, nr 56, s. 3-15.

Smoleń T. (2006), Produkt kultury - charakterystyka marketingowa, „Zeszyty Naukowe Akademii Ekonomicznej w Krakowie", nr 720, s. 87-100.

Węglarska K. (2013), Marketing jako „przyszłość” kultury, „Acta Humana”, nr 1, s. 138-152.

Zdebska-Schmidt J., My -Wy - Dom kultury w kontekście tworzących go ludzi, https://inspiro. org/2017/05/14/my-wy/ [odczyt: 23.02.2019].

\section{Netografia}

http://antybowling.bibel.pl/pakiet.php [odczyt: 20.02.2020].

http://ourmuseum.org.uk/wp-content/uploads/Community-Engagement-Strategy-2015-20-1. pdf [odczyt: 20.02.2020].

https://www.mnw.art.pl/wizyta/a-ty-co-zobaczysz/ambasadorzy/ [odczyt: 20.02.2020].

https://www.youtube.com/watch?v=tllTKgFiFE4\&list=PLqfyjXfxSQ5uwtWQJ6BXUjbarcjeU NafG [odczyt: 20.02.2020]. 